The Japanese Journal of Psychology

1974, Vol. 45, No. 4, 171-180

\title{
自由想起におけるリハーサル諸技法の効果 (1)
}

リハーサルの活動水準と活動部位指定の効果—

九州大学
山 快 生

THE EFFECTS OF REHEARSAL TECHNIQUES

IN FREE RECALL (1)

- THE EFFECTS OF REHEARSAL ACTIVITY

LEVELS AND DESIGNATION OF

ACTIVITY SECTION-

HAREO YAMAGUCHI

Department of Educational Psychology, Kyushu University

A series of 2 experiments in free recall was designed to investigate the effects of rehearsal techniques on serial position curve and recall order and also to examine the relationship between input order (serial position) and out put (recall) order. Ss were required to rehearse the list items for $30 \mathrm{sec}$ during the delay interval between presentation and recall. Rehearsal in the delay interval had more positive effects upon the items attributed to STS (last items of the list) than upon the items of other positions. In the rehearsal-delay recall as well as no-delay recall, the items being rehearsed in STS were recalled at the outset, and then the items retrieved from LTS were recalled.

直後自由想起課題においては，ふつらなんらかの項目 たとえば単語の幾つかが, 1つずつ被験者に提示される. 被験者は，あとで順序は問わずに，できるだけ多くの単 語を想起しなければならない。この結果から得られるる のは, 特徵のある系列位置効果を示す事はよく知られて いる. この場合, 想起の確率と提示に抹ける単語の位置 との関係は, 後部ピークより低い前部ピークを持つU字 型の系列位置曲線で示されらる. 多くの著者たら, たと えば Waugh \& Norman (1965), Glanzer \& Cunitz (1966), Murdock (1967), Atkinson \& Shiffrin (1968) は, このU字型をなす系列位置曲線は, 長期ストアメカ ニズムと短期ストアメカニズムの 2 つの記憶機構によっ て合成されていると仮定している.リストの前部から想 起された刺激材料は, 主として長期ストアからの出力で あるが, リストの後部から想起された刺激材料は, 主と して短期ストアからの出力であるとされる．この考壳 は，一般的に容認されているところである.

\footnotetext{
1 本研究にあたり，激励とご示唆をいただきました九 州大学教育学部三隅二不二教授, ご指導ご支援をいただ きました九州大学教育学部山内光哉助教授に感謝いたし ます。本研究の一部は, 日本教育心理学会第 14 回 (1972) 大会で発表された。
}

長期ストアメカニズムと短期ストアメカニズムとの区 別は, Hebb (1949) と Broadbent (1958) により展開さ れてきた.さらに, 短期ストアに関する研究は, Broadbent (1958), Brown (1958), Peterson \& Peterson （1959）等によって発展されてきた。同時にまた, これ らの長期・短期のメカニズムに影響を与える諸変数,す なわち, 現実的には, 系列位置曲線に影響を与える変数 については，数多くの研究がなされてきた．たとえば， 長期ストアに影響を与える実験的変数は, 学習材料の提 示速度 (Murdock, 1962 ; Raymond, 1969) やリストの長 さ(Murdock, 1962 ; Postman \& Phillips, 1965) 等であ るが, 一方短期ストアに影響を与える実験的変数は, 学 習刺激提示後想起までの経過時間，すなわち，遅延時間 である (Glanzer \& Cunitz, 1966 ; Postman \& Phillips, 1965）と言われている.

ところで, 長期・短期ストアはどのようにして成立し 検索されるのであろらか. この点に関し，Atkinson \& Shiffrin (1968) はさらにモデルを展開し，一時的な記 憶を行ら短期ストア (short-term store, STS) と永続 的な記憶を行う長期ストア (long-term store, LTS) と を独立した記憶の過程として区別し，有機体の感覚登録 器 (sensory register) を通って入ってきた入力刺激 
は,リハーサル諸過程の活動により短期ストアに一時的 に保持されると同時に，長期ストアへの転写が可能にな ると仮定した.このように，記憶システムを通る情報の 流れは, 感覚登録器に打ける環境からの入力の処理と短 期ストアへの登録ではじまる. 情報が短期ストアにとど まっている間に, その情報は長期ストアに転写される. そして，検索の段階では長期ストアにたくわえられてい る関連情報が賦活され, 短期ストアにはいると仮定され ている.しかし, これらの研究に特いては, 刺激入力順 位 (系列位置) と反応出力（想起）順位との関係が実験 的に明確にされていない，ただ上記のモデルとは関係な く, Deese \& Kaufman (1957) は直後自由想起に括い て系列位置と想起順位との関係を検討しているが, 本研 究に和けるようにさまざまな遅延条件下での自由想起法 では試みられていない。

そこで, 本研究では記憶システムを通る情報の流れを より詳細に検証するために次のような手順を踏む. 自由 想起に特ける直後想起括よび遅延想起での系列位置効果 と想起順位との関係を検討し，同時に遅延期での活動水 準の違いの効果を調へ，時系列に沿った想起の模様も見 るために想起の時間的経過 (想起累積曲線) をも検討す る. この最後の点は筆者の知る限り系列位置実験との関 連では試みられていない.

ところで，遅延期での活動水準のレベルの差異が系列 位置曲線に括よぼす效果を検討した研究はいくらかある （たとえば, Postman \& Phillips, 1965 ; Glanzer \& Cunitz, 1966 ; Anders, 1971 ; Jacoby \& Bartz, 1972) が，遅延期に積極的にリハーサルさせ，そのリハーサル がおよぼす効果を検討した研究はない。そこで実験 1 で 遅延期の活動水準のレベルの 1 つにリハーサル群を含め て検討する，また，実験 2 で STS 部位をうきだすため にリハーサル活動部位を指定する技法を組んでその効果 を検討する.

2 リハーサル緩衝器 (Rehearsal buffer) とは, 感覚 登録器を通って STS に入力された情報を, 限られた容 量でるって, この緩衝器にとどめて拈いて, この緩衝器 で復唱することにより忘却を防いだり、コード化した り，LTS に転写したりする機能をはたすと仮定された ものである. このリハーサル緩衝器は限られた容量の情 報しかとどめて特くことができないものであり，リスト の提示が始められたときには, その緩衝器はカラである が, 項目は順次, 緩衝器がいっぱいになるまでつめこま れる. それ以後は新しい項目が入ってくるにつれて、リ ハーサル緩衝器にすでに入っている古い項目の5ちの 1 つと固きかえられる：もし，その置きかえられた項目 は, LTS への転写が起きる前に STS で消隇されるな らば，永遠に消失してしまうと仮定されている.

\section{実 験 1}

直後自由想起においては, まず親近性効果として現わ れる短期ストア項目 (系列位置の終禾部位) から想起さ れていくだろう. 他方, Glanzer \& Cunitz (1966) は遅 延想起法をとれば, 親近性効果が消失することを示し た. それは遅延期中の插入課題によって項目が STS で のリハーサル緩衝器 (Rehearsal buffer) ${ }^{2}$ から離され遅 延期に消失するからであると考学られている (Atkinson \& Shiffrin, 1968, 1971). 筆者は, 遅延期に, 提示項目 が STS でのリハーサル緩衝器から離されないような操 作をすることによって提示項目の消失を減少させること はできないだろらかと考えた. そこで，遅延期にリハー サルを積極的に続けさせる群, 遅延期に挿入課題を含ま ないで単に待たせる群, そして遅延期に暗算を課す群を 設け，それからの効果の違いを検討した。

\section{方法}

被験者 被験者は中学 2 年生男女 104 名. 26 人を 1 群 とし, 計 4 群を設けた. 各群とも, ほぼ同数の男女が含 まれていた，知能偏差值に䋆いて 45-65 の範囲に属す る生徒で, 各群の平均值が等しくなるよう設定した. 実 験は実験条件 1 群ごとの集団実験であった.

学習材料および装置 梅本・森川・伊吹（1955）の無

No-delay

Presentation Recall

No-delay

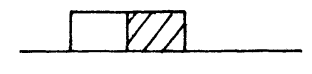

Delay-rehearsal

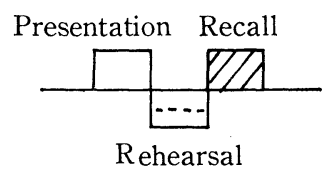

Delay-no inst.

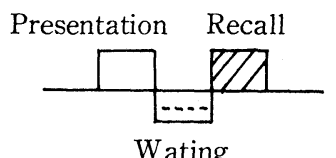

Wating

Delay-comput.

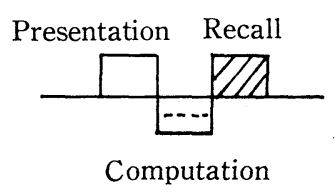

FIG. 1. The outline of Exp. I 
連想価 0-5 に属する 2 字ひらがな. 実験リストとし て，20 項目からなるリストを6 リスト. 練習リストと して，5項目からなるリストを 1 リスト。な拉，リスト 構成では各項目間に意味的関連がないように注意した. 各項目は, 透明な地に黒でプリントされたスライドに され, Kodak 社の Ektagraphic 改造自動プロジェク ター（竹井製作所製）で約 $5 \mathrm{~m}$ の距離から $1.5 \mathrm{~m} \times 2 \mathrm{~m}$ のスクリーンに視覚的に提示された.

手続 各群の実験手続きの概略は Fig. 1 に示す通り であった. 即ち,

（1）直後想起 (No-delay) 群：各リスト提示直後に 反応紙に 90 秒間自由想起記入を特こなった.

（2） 遅延想起（リハーサル；Rehearsal）群：“提示 された 20 個の言葉は，書いて下さいという合図がある まで，頭の中で口に出さないで何回方放方思い出棺 ていて下さい”といら教示後に，各リストを提示し，30 秒間のリハーサル後に, 反応紙に 90 秒間自由想起記入 を特こなった。

（3）遅延想起 (無教示; No-instruction) 群：“提 示された 20 個の言葉は，書いて下さいという合図があ るまで，書かないで文のまましばらく待っていて下さ い”といら教示後に各リストを提示し，30 秒間待たせ た後に, 反応紙に 90 秒間自由想起記入を持こなった。

(4) 遅延想起 (暗算; Computation) 群 : “提示され た 20 個の言葉は, 言葉の提示後に与えられる暗算問題 (この暗算問題は加算課題であり, 1 ケタ数字を 1 個 4 秒 の速さで実験者が読みあげて与えられた.)を計算して下 さい. その計算後に, 反応紙に書いて下さい”といら教 示後に, 各リストを提示し，30 秒間の計算後に, 反応紙

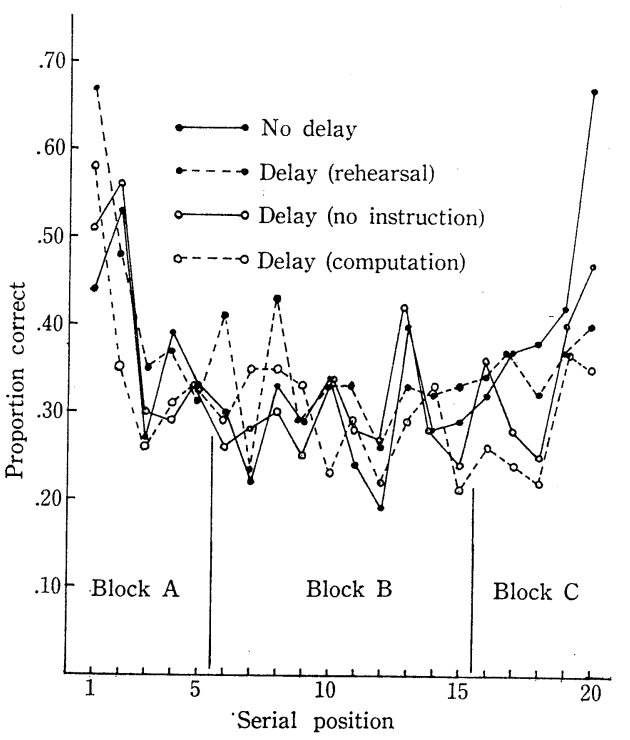

FIG. 2. Serial position curves for 4 conditions.
TABLE 1

Mean number of correct responses

\begin{tabular}{l|r|r|r|l}
\hline \multirow{2}{*}{ Conditions } & \multicolumn{3}{|c|}{ Position (block) } & \multirow{2}{*}{ Mean } \\
\cline { 2 - 4 } & A. 1-5 & B. 6-15 & C. 16-20 & \\
\hline No-delay & 2.377 & 1.727 & 2.577 & 2.227 \\
Delay-rehearsal & 2.669 & 2.004 & 2.177 & 2.283 \\
Delay-no inst. & 2.423 & 1.781 & 2.108 & 2.104 \\
Delay-comput. & 2.192 & 1.735 & 1.723 & 1.883 \\
\hline \multicolumn{1}{c|}{ Mean } & 2.415 & 1.812 & 2.146 & 2.124
\end{tabular}

に 90 秒間自由想起記入を特こなった.

各群に，5 項目からなる練習リストを提示し，それか ら実験リスト 6 系列を提示した. 1 項目を 1 秒間提示し, 項目間間隔は 2 秒であった. 想起終了後, 10 秒たった ら新しいリストの提示を開始した，被験者の想起用紙と して，25 cm $\times 18 \mathrm{~cm}$ の紙 7 枚を 1 部とした小冊子を与 えた. 7 枚のらち 1 枚は練習用であり， 6 枚は実験リス ト用であり，各ページは横に 10 個の欄が作ってあり左 の端には上から下の行にむけて 1 から 9 の数字がついて いる.

想起の手続きは，山内 (1959) の方法にならって，実 験に先立ってすでに与えられていた想起用紙の 1 行から 実験者の “始め” の信号と同時に書き始め, 10 秒ごと に次の行に移って書き続け，以下 9 行まで計 90 秒の想 起時間を与えた。なお，10 秒ごとの合図“次の行”は 実験者がストップ・ウオッチを見ながら与えた。さらに 項目の想起の順序は問わないこと, 同じ項目を 2 回書か ないこと，途中ではけっして質問しないことを認識させ た. 各リストの想起終了後, 直ちにそのページを閉じさ せ次の新しいページを開かせた．各群の実験時間は約 30一40 分であった. 実験は午前中静かな工作室で行な われた．実験の終了した群の被験者がそうでない群と情 報交換をすることは一切できないよう配慮された. 実施 は，一貫して筆者と学習心理学を専攻する 1 名の大学院 生が行ない, 教示が各群に等しくなるように注意が払わ れた。また，実験の意図に気づかれないよらにするため

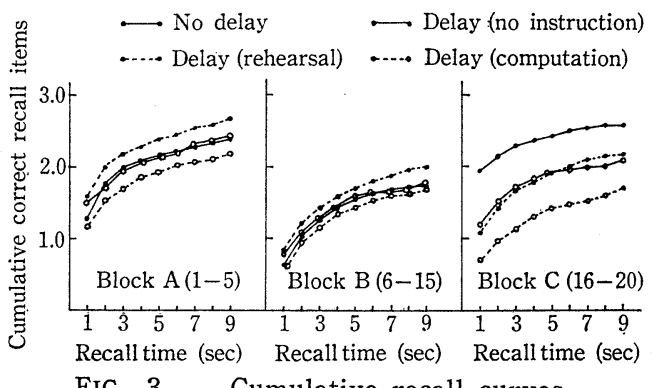

FIG. 3. Cumulative recall curves. 
に“この実験の目的は，みなさんが日頃どのように言葉 を憶えて使用しているかを知ることです”と教示した。

\section{結果}

反応を採点する場合，（1）各リストに含まれている項 目特よび，(2) 各リスト内で同じ項目が 2 回書いてあれ ば，最初に書かれた項目を正反応とした。

\section{1. 想 起 量}

各条件群下で各項目位置の正反応の比率を求めて，通 常の系列位置曲線を描いて示したものが Fig. 2 である. また， 6 リストの平均正反応の想起累積曲線を時間単位 (10 秒) ごとに示したものが, Fig. 3 である.

系列の位置をそれぞれ，(A) 1-5，(B)6-15，(C) 16-20 のブロックにわけ，その位置ごとの 6 リストについての 平均想起数（90秒まで）を Table 1 に示した. さらに, この得点についての分散分析 ${ }^{3}$ ( 4 想起条件を被験者間 とし，3 位置ブロックと想起条件と位置ブロックの交互 作用を被験 者内とする 2 要因混合計画) (Lindquist, 1953）を特こなったところ，条件群間に $F(3,100)=$ $3.434, p<.025$ で有意, 位置ブロック間に $F(2,200)=$ $23.158, p<.001$ で有意, さらにそれらの交互作用 $(F$ $(6,200)=2.645, p<.025)$ に拈いて有意であることが 認められた，そこで，想起条件 (Table 1 の最後の欄参 照) それぞれの間の群間比較をおこなったところ，遅延 想起 (リハーサル) 群は遅延想起 (暗算) 群よりも $t$ $(100)=2.87, p<.01$ で, また直後想起群は遅延想起 (暗算) 群よりも $t(100)=2.00, p<.05$ で有意に正反応 数が大であることがわかった。ささらに交互作用が有意で あったので，分散分析を次の 3 つのブロック，(A) 1-5, (B) 6-15，(C) 16-20，ごとに試みた. その結果，ブロッ ク $\mathrm{A}$ ，ブロック $\mathrm{B} に$ 特いて群間に有意差は認められない が,ブロック Cに和いてのみ有意差が認められた $(F(3$, 100) $=5.222, p<.01)$. ブロック Cに拈いて, 群間比較 をしてみると直後想起群は暗算群と無教示群より有意に 想起量が多く $(t(100)=3.948, p<.001, t(100)=2.168$, $p<.05)$ ，またりハーサル群は暗算群より有意に想起量 が多い $(t(100)=2.099, p<.05)$ ことがわかった.

\section{2. 想 起 順 位}

想起順位は，各りストごとの正反応・誤反応を含めて 1 行目に想起記入されている左端の項目から右端の方の 項目へ, 次に 2 行目へ, 以下同様に 9 行目まで順次番号 をつけていくことによって求められた. 結局, 有効なる

\footnotetext{
3 各ブロックの項目数は異なるが，各ブロックに括け る各個人の平均值に基づいて分析を行なった。

4 Deese \& Kaufman (1957) は，想起順位代表值を各 系列位置での平均值で求めているが，これは統計学的に 問題がある，順序尺度であるので，平均值ではなく，む しろ中位数で求めるべきであろう。
}

のとして使用された項目は正反応の項目の番号であっ た。

Fig. 4 に各群の正反応の想起順位曲線を示す. 各曲線 は 26 人により想起された 6 リストを示す. 各群の各系 列位置での想起順位数は各系列位置での中位数 ${ }^{4}$ を示す.

明らかに, 直後想起群は, 最後の数項目を最初に想起 しているが, 他の 3 つ遅延想起群にはそのような著し い傾向はみられず, 逆に最初の数項目を最初に想起して から他の位置項目の想起に移っている.

\section{3. 想起率と想起順位との相関}

想起率の高い位置項目は想起順位に䋆いても早く想起 されるのかどらか，すなわち，想起順位の早い位置項目 は想起率に捈いても高いかどらか。 そこで，想起率と想 起順位の関係を Kendall の順位相関係数 $(\tau)$ で求めた。 その結果,

直後想起群 $: \tau=.368$, 有意性あり $(p<.05)$

遅延想起（リハーサル群） $\tau=.468$, 有意性あり（ $p<$ .01)

遅延想起 (無教示) 群 : $\tau=.148$, 有意性なし (n.s.) 遅延想起（暗算）群 : $\tau=.278$, 有意性なし (n.s.) となっている.

\section{考察}

本研究の主な目的は, 活動水準の level の差異を吟味 し, 遅延期に提示項目が STS でのリハーサル緩衝器か ら離されないよらな操作をすることによって, 提示項目 の消失を減少させることができるかどうか，といらこと

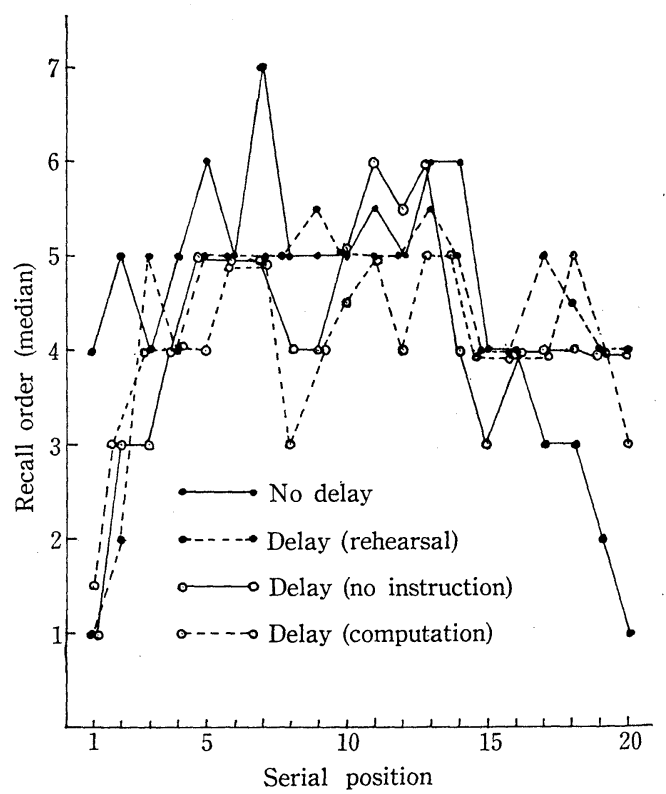

FIG. 4. Recall order curves for 4 conditions. 
とさらに遅延期での活動水準の違いの効果を検討するこ とであった，そこで，まず想起量について吟味する.

\section{(1) 想 起 量}

系列位置曲線は, 直後想起群に括いて典型的な $\mathrm{U}$ 字型 を示していることがわかる.すなわち，初頭部位と終末 部位の確率は高く，とくに，終末部が大である. しか し,他の群でに終末部の欠損が生じて和り,リハーサル群 ですらこのような低下を完全に防ぐことはできていない．

全体的想起量では, 高い方から (1) リハーサル群 (2) 直 後想起群 (3) 無教示群 (4) 暗算群の順位になっていること がわかった。ささらに系列の前部, 中部では, 群間に有意 な想起量差が見出されなかったが後部では，有意が見出 され, (1) 直後想起群 (2) リハーサル群 (3) 無教示群 (4) 暗 算群の順位になっていた. しかも, 暗算群とリハーサル 群の間に有意差がみられている。このことより, 遅延期 飞提示項目をSTS でのリハーサル緩衝器から離されな いような操作をすることによって，提示項目の消失を減 少させることができると考兄られる。

遅延期にリハーサルを和こなわせる群を設定してはい ないが, 活動水準を変光た他の研究で, この研究と比較 しらる群の成績を吟味してみると, 全体的想起量に関す る結果は, (1) 直後想起群 (2) unfilled retention（遅延期 飞被験者の自由にまかせて挌く条件) 群 (3) filled retention（通延期飞暗算を与兄られる条件）群の想起量順位 を示した Anders (1971) と一致したが, (1) unfilled retention 群 (2) 直後想起群 (3) filled retention 群の 順 位を示した Jacoby \& Bartz (1972) とは一致しなかっ た.

一般飞遅延想起法は, 系列位置曲線の終末以前の部位 (ブロック A, B) 飞影響を与えないが，終末部位に影響 を与えるとされている (Postman \& Phillips, 1965； Glanzer \& Cunitz, 1966 ; Atkinson \& Shiffrin, 1971). ところが, 本研究の Fig. 3 と Table 1 を視察すれば, ブロック Aとブロック B が，しかし傾向としてリハーサル群が直後群より高い想 起量を示していることがうかがわれる，結論を出すため にはな特多くの実験を必要としよらが，一応遅延期の積 極的リハーサルが，LTS からの出力と考兄られている 系列の前部, 中部の項目の保持㐫促進的効果を与える 傾向があると思われる。このような結果から, 遅延想起 法は一義的に終末部位 (STS) 飞のみ影響を与えるとは 言えず，その仮設は部分的事実として受けとらなくては ならないのではあるまいか，それは遅延期の活動水準の 在り方いかんによると言光よう。

系列の終末部位に挌ける結果は, 一般的㳄次の上うに 考察されらる. 自由想起に和ける系列の終末部は, 主と して STS からの出力による (Glanzer \& Cunitz, 1966 ; Murdock, 1967 ; Atkinson \& Shiffrin, 1968).
た, STS に打ける項目の保持時間は短く, しかもSTS 飞特ける保持許容量は限られて呿り, 古い項目は新しく 入力された項目により置きかえられる(Waugh \& Norman, 1965 ; Atkinson \& Shiffrin, 1968) と仮定さ れている，直後想起群では，終末位置項目の保持時間は 相対的に短かく，乙か子終末部位項目は他の項目々置き かえられるといらことがほとんどないであるう．他方， 3つの遅延想起群について考えると, 3 つとも遅延時間 は同じであるが, 暗算群では終末部位項目が暗算課題に よって置きかえられるか，もしくは，それに妨害されるこ とによって消失されるといら確率が相対的飞最も高いと 考えられる、ところが, リハーサル群では他の項目と置 きかえられる確率が最も低いと考兄られ，しかもリハー サルを積極的に続けることによって無教示群に和けるよ りる保持を高めることができると考学られる．以上のよ らな理 由で, (1) 直後群 (2) リハーサル群 (3) 無教示群 (4) 暗算群の順位が示されたものと説明できよう。とくに， 直後想起群と暗算群に有意差があると同様に、リハーサ ル群と暗算群に有意差があることは, 実質上かなりの程 度りハーサルが忘却を防止しうることを意味していると 言える.

な特, 終末部について, 本研究の一部と重なり合う他 の研究と比較したところ, 次の異同が示された。系列位 置の後部（ブロックC）での想起量に関する結果は, (1) 直後想起群 (2) 遅延（暗算）群の順位を示した研究 (Postman \& Phillips, 1965 ; Glanzer \& Cunitz, 1966; Jahnke, 1968) や (1) 直後群 (2) 遅延 (無教示) 群 (3) 遅 延（暗算）群の順位を示した Anders (1971) と一致し たが，(1) 直後群う遅延（無教示）群 (2) 遅延（暗算）群 の順位になった Jacoby \& Bartz (1972) とは一致しな かった

\section{（2）想起順 位}

直後想起群では, 系列の最後の数項目がすず最初に想 起され，次に第 1 位置項目が想起された. 3 つの遅延想 起群では, 最初の数項目が最初に想起されてから, 次に 他の位置項目が想起された. 直後想起群の結果は, 本研 究のように中位数ではなく平均值で求めた Deese \& Kaufman (1957) と一致し，また直後自由想起に打いて は最後の項目が提示されたときにな和りハーサル緩衝 器でリハーサルされている諸項目がただちに想起される といら理論 (Atkinson \& Shiffrin, 1971) を支持する ものである. 一方, 3 つの遅延想起群のうち, 暗算群の 結果は次のように考察されらる。暗算をすることが, STS でリハーサルされている全部の単語を消失させ, 従ってそこに想起されるものは LTS から検索されたも のにかぎられるという理由, もら一つは, 想起率の高い 位置項目（この場合には，第 1 位置項目）は想起順位も 早い (Deese \& Kaufman, 1957) という理由から, 結 
TABLE 2

The Layout of Exp. 2

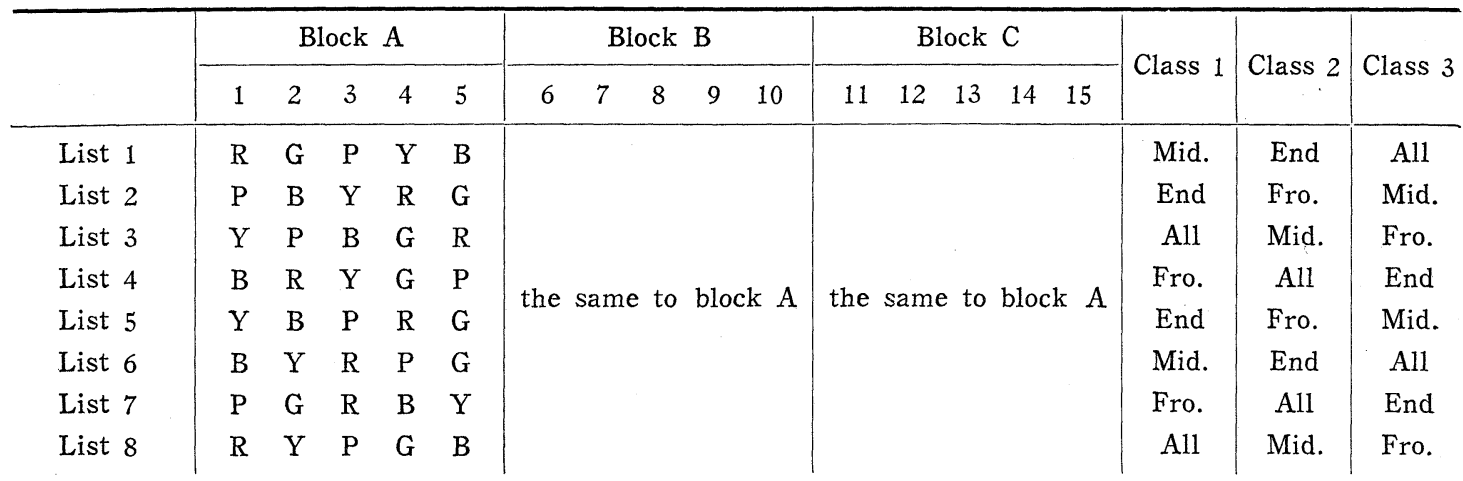

Notes : R (red), G (green), P (purple), Y (yellow), B (blue) Color names designate the colors of the paraffine papers used as the scene of each item.

Fro. (front section rehearsal), Mid. (middle section rehearsal)

End (end section rehearsal), All (all sections rehearsal)

TABLE 3

Mean number of correct responses

\begin{tabular}{c|c|c|c|c}
\hline \multirow{2}{*}{ Conditions } & \multicolumn{2}{|c|}{ Position (block) } & \multirow{2}{*}{ Mean } \\
\cline { 2 - 4 } & A. 1-5 & B. 6-10 & C.11-15 & \\
\hline Fro. sect. rehearsal & 1.105 & 0.626 & 0.687 & 0.806 \\
Mid. sect. rehearsal & 1.087 & 0.767 & 0.733 & 0.862 \\
End sect. rehearsal & 1.049 & 0.685 & 0.910 & 0.881 \\
All sect. rehearsal & 1.121 & 0.731 & 0.690 & 0.847 \\
\hline Mean & 1.091 & 0.702 & 0.755 & 0.849
\end{tabular}

TABLE 4

Analysis of variance of correct responses

\begin{tabular}{|c|c|c|c|c|}
\hline Source & $d f$ & $M s$ & $F$ & $p$ \\
\hline Rehearsal (A) & 3 & 5.99 & 2.39 & \\
\hline Position (B) & 2 & 345.97 & 95.36 & $<.001$ \\
\hline Subjects $\quad(\mathrm{S})$ & 77 & 12.87 & & \\
\hline$A \times B$ & 6 & 12.43 & 4.58 & $<.001$ \\
\hline$A \times S$ & 231 & 2.50 & & \\
\hline $\mathrm{B} \times \mathrm{S}$ & 154 & 3.63 & & \\
\hline$A \times B \times S$ & 462 & 2.71 & & \\
\hline Total & 935 & & & \\
\hline
\end{tabular}

果を説明できよう．ところが，リハーサル群と無教示群 の結果はどらであろらか。遅延期に被験者は少なくとも ぞれかの位置項目をSTS 内でリハーサルしているはず である，仮に系列の終末部位項目をリハーサルしていた ならば, 想起時点では, その項目が最初に想起されるる のと仮定される.
もし，前部の位置項目がリハーサルされていたならば， その前部の項目が最初に想起されると仮定される，結果 は，後者の仮定を支持するものであった，しかしなが ら，本実験はリハーサル部位を指定していないこと， covert (silent) リハーサルがなされたことから，被験者 がどの部位項目をリハーサルしていたのかはわからない。

\section{（3）想起率と想起順位との相関}

直後群とリハーサル群は有意な相関を示したが，無教 示群と暗算群は有意な相関を示さなかった，本研究の直 後群の結果は, .368 の相関值を示したが, Deese \& Kaufman (1957) は 10 項目リストの場合に.867, 32 項 目リストの場合に.536 の相関值を示した. 本研究の結 果は一般に低い値を示している. しかし, Fig: 2 と Fig. 4 をこまかく視察してみると, 系列の前部項目特よ び後部項目に扣いて，想起率が高ければ想起順位も早い ということが読みとれる. Fig. 4からわかるように，リ ストの中部で同順位が多く示された. このことは低い相 関を示した理由の一つになるかもしれない.

\section{実 験 2}

実験 1 に拉いて, 活動水準の異なる想起条件間に有意 な想起量の差が認められた。すなわら，遅延期にリハー サルする条件下では暗算課題を行ら条件下よりる想起量 が多い結果が得られた。しかし、すでに考察したよら に, リハーサルの効果は, ブロック A, ブロック Bにも あらわれ，とくに STS の出力と見なされるブロックC への効果が稀薄になっているのではないかと考えられ る.したがって，ブロックCをリハーサル部位として指 定して見れば，リハーサルの効果はいっそら明確になり はしないかと思われる。そこで，本実験では，全般的な 
計画として，当のブロックCだけではなく，他のブロッ ク A,B をもリハーサルの対象として含めた。 つまり, 遅延期にリハーサルを特こなう部位項目を指定すること によって，その部位項目の想起量括よび想起順位に促進 的効果を与えることができるかどうかを検討する.

\section{方法}

被験者 被験者は中学 2 年生男女 78 人. 26 人を 1 群 と乙計 3 群. 実験は 1 群ごとの集団実験であった。知能 編差值に拈いて 45一65 亿属する生徒であった。

学習材料および装置 学習材料括よび装置は実験 1 と 同じ. 実験リストとして, 15 項目からなるリストを 8 リ スト．練習リストとして，2桁数字項目で 15 項目からな るリストを1リスト．すべての項目はスライドにした。 *印をリストの出発合図として使用した.

各項目のスライドに色のついた透明なせロファン紙を はりつけた. 従って, スクリーンKプロジェクターで提 示されると各項目はセャファン紙の色を背景としてその 文字が映し出された。 5 色 (赤, 緑, 紫, 黄, 青) のパ ラフィン紙をどのリストにも用いた。 この色を使う理由 は, 被験者が 3 つの系列位置ブロックを区別する際に手 がかりとしてそれを利用させるためである.

Table 2 飞示す通り，各リスト内では，5色の各々が， 前ブロック，中ブロック，後ブロックの各々に招いて 1 回ずつ使用された、リストごとに，色の配置順序は異な っていた．提示方法は実験 1 と同じであった.

手続 各リスト提示直後に, 実験者が次の 4 つの部位 のらち 1 つをッーサルするよう口頭で指示し， 30 秒間

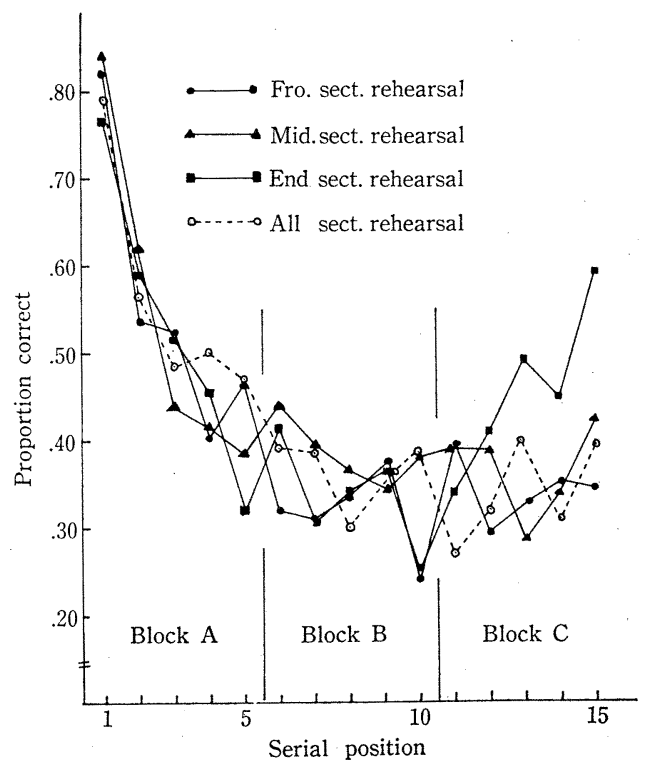

FIG. 5. Serial position curves for 4 conditions.
遅延期にその部位をリハーサルさせた。 その後に 90 秒 間の想起時間を与兄た．想起の手続きは実験 1 の場合と 同様であった。

リンーサルの指定部位は, (1) 前部位 (1-5 位置項目), (2) 中部位 (6-10 位置項目), (3) 後部位 (11-15 位置項 目), (4) 全体部位（1-15 位置項目) の 4 つであった. リハーサルの指定は具体的に次のようになされた。“15 個の言葉の提示後に,リハーサル部分といって，例光ば ‘前の部分を思い出して下さい’ と指示されたら，30 秒 間反応紙飞書かないで, 最初の 5 らの言葉を頭の中で口 飞出さないでしっかり思い出していて下さい。この 30 秒間のリハーサル後に ‘書いて下さい’ と指示された ら，15 個の言葉すべてを提示された順序に関係なく思い つくままに反応轱飞書いて下さい、リハーサルの指定部 位は, この他に中, 後, 全体部位の計 4 つあり, ランダ ム飞指示します、リストの言葉は, 前の 5 つ, 中の 5 つ, 後の 5 つに, それぞれ 5 つの色が使われていますの で，みなさんにりストが提示される時に 5 色を手がかり として部位分けをして下さい”。

な特、リハーサル部位の指示は各リスト提示直後に与 えられるので, 被験者はリスト提示前または提示中に指 定部位を予想して学習することができなかったと思觉 る、リハーサルする部位はリストごとにランダムに変え られ, 前, 中, 後, 全体リハーサルを各被験者にそれぞ れ 2 回経験させた。

\section{結果}

反応の採点の方法は実験 1 の場合と同様であった。

\section{1. 想 起 量}

各リハーサル条件ごとに正反応の比率を求めて，通常 の系列位置曲線を描いて示したものが Fig. 5 である。ま た, 2 リストの平均正反応の想起累積曲線を時間単位ご とに示したものが Fig.6である.

系列の位置をそれぞれ，(A) $1-5 ，$ (B) $6-10 ，$ (C) 11-15 のブロックにわけ，その位置ごとの 2 リストに ついての平均想起数 (90 秒まで)を Table 3 に示した. さらに, Table 4 には, この得点についての分散分析 (処理 (4リハーサル条件) $\times$ 処理（3位置ブロック）× 被験者計画) (Lindquist, 1953) を特こなった結果が示

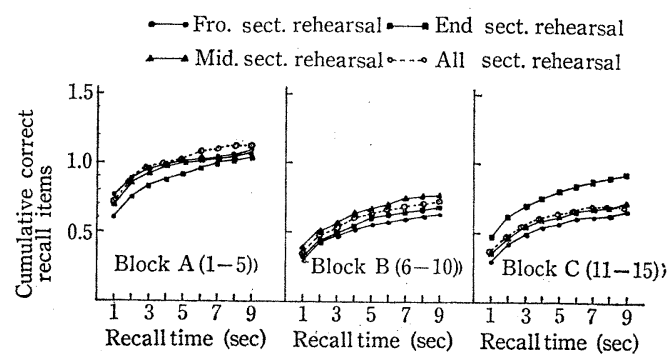

FIG. 6. Cumulative recall curves. 
されている.

その結果，条件間には有意に近い傾向 $(.10>p>.05)$ が，位置ブロック間に有意差が，さらにとれらの交互作 用も有意であることが認められた．交互作用が有意であ ったので，分散分析を次の 3 つのブロック（(A) 1-5位 置, (B) 6-10 位置, (C) 11-15 位置) ごとに試みた. その結果，(A) 位置に拉いて群間に $F(3,231)=0.711$, で有意でなく，(B) 位置に和いて群間に $F(3,231)=$ $3.168, p<.025$, で有意, (C) 位置に捛いて群間に $F$ $(3,231)=7.210, p<.001$ ，で有意であることが認めら れた。（B）位置に抒いて，群間比較をしてみると，中 リハーサル君：は前リハーサル群より $t(231)=2.912, p$ $<.01$ ，で，全体リハーサル群は前リハーサル群より $t$ $(231)=2.173, p<.05$ で有意に正反応が大であること がわかった．また，（C）位置に沶いて，後リハーサル 群は前リハーサル群, 中リハーサル群, そして全体リハ 一サル群よりそれぞれ $t(231)=4.01, p<.001, t(231)$ $=3.18, p<.01, t(231)=3.96, p<.001$, で有意に正 反応が大であることがわかった。

\section{2. 想 起 順 位}

想起順位の求め方は実験 1 の場合と同様である.Fig. 7 に各群の正反応の想起順位曲線を示す. 各曲線は 78 人より想起された 2 リストを示し，各群の各系列位置で の想起順位数值は各系列位置での中位数を示す. 前, 中, 全体リハーサル群では, 最初の位置項目が最初に想起さ れた. 後りハーサル群では, 最後の位置項目が最初に想 起された.

\section{3. 想起率と想起順位との相関}

想起率と想起順位の関係を Kendall の順位相関係数

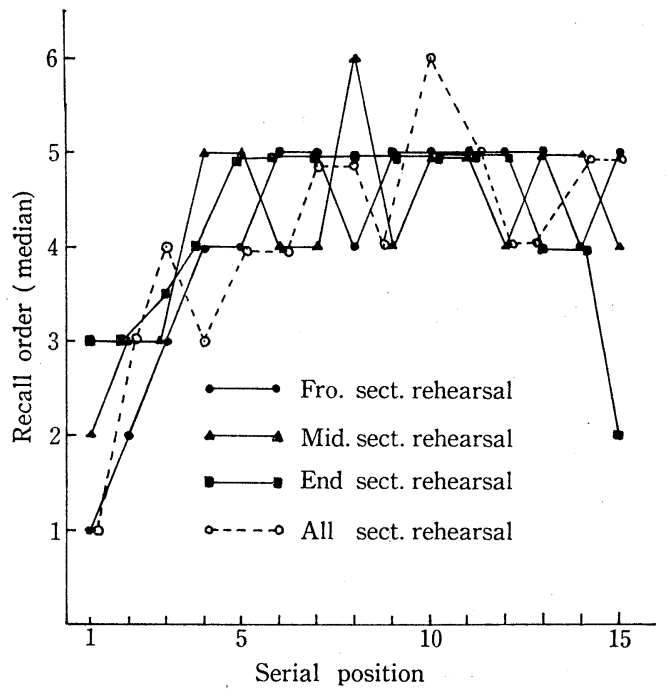

FIG. 7. Recall order curves for 4 conditions.

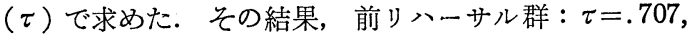
有意性あり. $(p<.001)$, 中リハーサル群 : $\tau=.637$, 有 意性あり $(p<.001)$, 後リハーサル群 $: \tau=.773$, 有意 性あり $(p<.001)$, 全体リハーサル群 : $\tau=.648$, 有意 性あり $(p<.001)$ となっている.

\section{考察}

本研究の目的は, 遅延期に特定の部位項目のみをリハ 一サルすることが，系列位置曲線および想起順位にいか なる効果を与えるかを検討することであった。

（1） 想起量 想起量に関して, 全体的想起量におい ては，条件間に有意に近い傾向が認められ，ブロック では有意差がなかったが，ブロック Bとブロック Cに抹 いて有意差が認められた，その際に，ブロックBでは中 リハーサル群が，ブロックCでは後リハーサル群が最も 多い想起量を示した.すなわち,ブロック $\mathrm{B}, \mathrm{C}$ では, それぞれのリハーサル指定部位の効果があがっているこ とがわかる. また, 後リハーサル群は通常の直後想起群 によるものと非常に類似したU字型の系列位置曲線を示 したが, 前, 中, 全体リハーサル群は首位効果を残留し ているものの，親近性効果を消失した.

実験 1 の結果から，何ら特定部位を指定しないが，遅 延期にとにかくリハーサルすることは想起量に促進的効 果を与えるといらこと，とりわけ STS からの出力とさ れる終末部位に捈いてその効果が最も大きいといらこと が明らかになった. さらに，実験 2 の Fig. 5 と Fig.6 からもはっきりわかるように, リハーサルの効果はブロ ックCに捈いて著しく，ついでブロック Bとなってい る.このようにリハーサル部位を指定する場合にも，リ ハーサルの効果はSTS に帰せられる部位に拈いてより 強いことを物語っている.

ところで, ここで, 後リハーサル群の終末部位項目の ピークは, 直後群のU字型の曲線 (Fig. 2 参照) と類似 していた. このことから, 後リハーサル群のピークは直 後群のように STS からの出力と考えられらるだろら か. Waugh \& Norman (1965) の理論によれば, STS に和ける項目は，新しい項目によって置きかえられる。 その置きかえられた項目は，次の 3 つの場合が考えられ らる.（イ）STS から欠落し，消失する。（ロ）リハー サルされることによって STS に保持される．（ハ）LTS に転写され，保持される．さらに，リハーサルは，入力 項目をSTS にとどめておくといら機能と LTS へその 項目を転写させる確率を高めるという機能の 2 つを持っ ているとされている.（同様な見解は，Anders (1971) や Kintsch (1970) にも見られる.) このように，リハー サルは 2 つの機能を持っていることから仮定すれば，本 研究での後リハーサル群のピークは, (1) STS のリハー サル緩衝器にとどめていて, 想起時にとこから出力され 
る，(2) 遅延期のリハーサル過程で LTS にその項目は転 写されて, 想起時に LTS から STS へ引き出されて出 力される，いずれかあるいは両者が可能であろう．乙か しながら、この点についてはさらに検討する心要がある だろう。

（2）想起順位 前, 中, 全体リハーサル群では系列 の最前部の項目が最初に想起されたが, 後りハーサル群 では終末部位項目が最初に想起された。本実験の手続き から考えると, 遅延期に部位を指定し、リハーサルさせ るのであるから，それらの項目が最初に出力されるだろ らと当然期待されらる. その結果, 前リハーサル群之後 リハーサル群は期待されたものを示したが，中リハーサ ル群はまったく期待を支持しえないるのであった，この 支持しえなかった理由として, 本実験では被験者が $3 つ$ の部位ブロックを分割区別しやすいように色を使用した のであるが，被験者にとって前後に同様の手掛りがある ために十分な手掛りになりえなくて, 中ブロックの項目 をうまく LTS から検索し，リハーサルすることができ なかったことが考觉らる。

（3） 想起率と想起順位との相関 ぞの条件において も, かなり高い相関值 $(.65$ 一. 77 , いずれも $p<.001)$ が示された。この結果は, 実験 1 の場合より著しく高 い.この違いは, リスト項目数の差によること,リハーサ ル部位を指定したことによるのかもしれぬ. 事実, Deese \& Kaufman (1957) は, 10 項目リストで.867， 32 項 目リストでは.536を示した. 以上の結果より, 想起率 の高い位置項目は想起順位に和いても早く想起されるこ とが確認されたと言えるだろう。

\section{要 約}

自由想起に括けるリハーサル諸技法が系列位置と想起 順位に拈よぼす効果を検証し，さらに，記憶システム (STS と LTS) に拈ける入力順位 (系列位置) と出力 （想起）順位との関係を検討するために, 2 つの実験が 計画された.

実験 1 亿抢いて, 提示と想起との間の遅延期に提示項 目をリハーサルすることによって, 提示項目の消失を減 少させることができるのではないかと仮定し，遅延期に リハーサルを積極的に続けさせる群, 遅延期に挿入課題 を含ませないで単に待たせる群, そして遅延期に暗算を 課す群を設け, それらの効果の違いを検討した。

実験 2 に打いて, 提示值後にリハーサルする部位項目 (前部, 中部, 後部, 全体部位のいずれか)を指定し, そ の指定部位をりハーサルすることがその部位項目の想起 量和よび想起順位にいかなる促進的効果を与えることが できるかどらかを検討した、な挌，いずれにおいても遅 延時間は 30 秒間であった.

実験 1 の主要な結果は次の通りであった（1）想起量
に関して; 遅延期の活動水準の異なる想起条件間に有意 な想起量の差が認められた。すなわち, 遅延（リハーサ ル）群に特いては遅延（暗算）群に扣いてよりも想起量 が有意に多いといら結果が得られた。 その際に, 遅延期 のリハーサル効果は系列の前部, 中部にも現われる傾向 がうかがわれたが，とくに終末部に执いて有意に大きか った。（2）想起順位に関して; 直後想起群では終末部位 項目が最初に想起され, 次に最前部の位置項目が想起さ れた. 3 つの遅延想起群では系列の最前部の位置項目が 最初に, 次に他の部位項目が想起された。

実験 2 の主要な結果は次の通りであった。（1）想起量 に関して；リハーサルの活動部位指定の効果は, リスト の中部, 後部において現われた。すなわち, 中部に敊い ては中リハーサル群が, 後部に执いては後りハーサル群 が著しく，他の群より有意に高い想起量を示した。（2） 想起順位に関して; 前, 中, 全体リハーサル群では系列 の最前部の項目が最初に想起された. 後リハーサル群で は終末部位項目が最初に想起された。

以上の結果から, 遅延期に括ける指定されたリハーサ ルの効果は, STS に帰せられる部位に近い項目にほど, 他の部位 (LTS) に和けるよりも強く現われることが確 認された。 また，本実験で設定したリハーサル遅延想起 の場合も直後想起の場合と同様に, STS でリハーサル されている項目が最初に想起 (出力) され, 次に LTS から検索された項目が想起されることが示唆された.

\section{引用 文 献}

Anders, T. R. 1971 Short-term memory for serially presented supraspan information in nonretarded and mentally retarded individuals. American Journal of Mentally Deficiency, 75, 571-578.

Atkinson, R. C., \& Shiffrin, R.M. 1968 Human memory : A proposed system and its control processes. In K.W. Spence \& J. T. Spence(Eds.), The Psychology of learning and motivation: $A d-$ vances in research and theory. Vol.2. New York: Academic Press, Pp. 89-195.

Atkinson, R. C., \& Shiffrin, R. M. 1971 The control of short-term memory. Scientific American. (船 津孝行訳 1971 記憶をコントロールする機構 サイ エンス 11 月号 日本経済新聞社)

Broadbent, D.E. 1958 Perception and Communication. New York : Pergamon.

Brown, J. 1958 Some tests of the decay theory of immediate memory. Quarterly Journal of Experimental Psychology, 10, 12-21.

Deese, J., \& Kaufman, R.A. 1957 Serial effects in recall of unorganized and sequentially organized verbal material. Journal of Experimental Psychology, 54, 180-186.

Glanzer, M., \& Cunitz, A.R. 1966 Two storage 
mechanisms in free recall. Journal of Verbal Learning and Verbal Behavior, 5, 351-360.

Hebb, D. O. 1949 The Organization of Behavior. New York; Wiley.

Jacoby, L. L., \& Bartz, W.H. 1972 Rehearsal and transfer to LTM. Journal of Verbal Learning and Verbal Behavior, 11, 561-565.

Jahnke, J.C. 1968 Delayed recall and the serialposition effect of short-term memory. Journal of Experimental Psychology, 76, 618-622.

Kintsch, W. 1970 Learning, Memory, and, Conceptual Processes. New York: Wiley.

Lindquist, E.F. 1953 Design and analysis of experiments in psychology and education. Boston: Houghton Mifflin.

Murdock, B. B. 1962 The serial position effect of free recall. Journal of Experimental Psychology, 64, $482-488$.

Murdock, B. B. 1967 Recent developments in shortterm memory. British Journal of Psychology, 58,
$421-433$

Peterson, L. R., \& Peterson, M. J. 1959 Short-term retention of individual verbal items. Journal of Experimental Psychology, 58, 193-198

Postman, L., \& Phillips, L. W. 1965 Short-term temporal changes in free recall. Quarterly Journal of Experimental Psychology, 17, 132-138.

Raymond, B. 1969 Short-term storage and longterm storage in free recall. Journal of Verbal Learning and Verbal Behavior, 8, 567-574.

梅本堯夫・森川弥寿雄・伊吹昌夫 1955 清音 2 字音節 の無連想価及び有意味度心理学研究, 26, 148-155.

Waugh, N.C., \& Norman, D. A. 1965 Primary memory. Psychological Review, 72, 89-104.

山内光哉 1959 意味度执よび呈示回数を変えた場合の 想起の時間的特色について 心理学研究， 30, 208一 211.

- 1974. 2. 26. 受稿—

\section{SUMMARY}

A series of 2 exeriments in free recall was designed to investigate the effects of rehearsal techniques on serial position curve and recall order and also to examine the relationship between input order (serial position) and output (recall) order.

In Exp. 1, the hypothesis was that the loss of list items presented can be reduced by rehearsing them during the delay interval between presentation and recall. Four groups of no-delay, delay-rehearsal, delay-no instruction, and delay-computation were used.

In Exp. 2, the effects of rehearsal of items at the designated positions (front, middle, end, and all sections) on the recall and recall order were examined. In both experiments, the delay interval was $30 \mathrm{sec}$.

The main results of Exp. 1 were as follows. (a) Regarding the recall data, the significant difference of recall was found between the 4 conditions, differing in the activating level in the delay interval. The delay-rehearsal group showed more recall than the delaycomputation group. Rehearsal during the delay interval showed a tendency to have positive effect in the front and middle sections, and its effect was statistically significant in the end section. (b) Regarding the recall order, in no-delay condition the end items were recalled at the outset, and then the front items were recalled. In 3 delay conditions, the front $i$ tems were recalled at the outset, and then the items of other positions were recalled.

The main results of Exp. 2 were as follows. (a) Regarding the recall data, designation of the rehearsal activity had significant positive effects upon the recall of items in the middle and end sections of the list. The middle section rehearsal group significantly recalled more items in the middle section than other groups. The end section rehearsal group significantly recalled more items in the end section than other groups. (b) Regarding the recall order, beginning items were recalled at the outset in all groups except the end section rehearsal group, while in the latter group the end position items were recalled at the outset.

From these results, rehearsal during the delay interval had more positive effects upon the items attributed to STS (last items of the list) than upon the items of other positions. In the rehearsal-delay recall as well as no-delay recall, the items being rehearsed in STS were recalled at the outset, and then the items retrieved from LTS were recalled. 